\title{
Effect of Cooking on Residues of the Quinolones Oxolinic Acid and Flumequine in Fish
}

\author{
By I. Steffenak, V. Hormazabal and M. Yndestad \\ Department of Food Hygiene, Norwegian College of Veterinary Medicine, Oslo, Norway.
}

\begin{abstract}
Steffenak, I., V. Hormazabal and M. Yndestad: Effect of cooking on residues of the quinolones oxolinic acid and flumequine in fish. Acta vet. scand. 1994, 35, 299-301. - The effect of cooking on residues of the quinolones oxolinic acid and flumequine in fish was investigated. Salmon containing residues of oxolinic acid and flumequine was boiled or baked in the oven. Samples of raw and cooked muscle, skin, and bone, as well as of the water in which the fish was boiled and juice from the baked fish, were analysed. Oxolinic acid and flumequine did not degrade at the temperatures reached when cooking the fish. However, fish muscle free from drug residues may be contaminated during boiling and baking due to leakage of the drug from reservoirs in the fish.
\end{abstract}

\section{heat treatment.}

\section{Introduction}

The quinolone oxolinic acid, much used for the treatment of infectious diseases in farmed fish, has been the most used drug in Norwegian aquaculture during the last three years. In 1991, 11.4 metric tons of oxolinic acid were employed, in addition to 5.7 tons of flumequine (Nafstad 1992).

Earlier we have found that residues of quinolones may persist in fish, especially in skin and bone, for prolonged periods after end of treatment, even though muscle and possibly liver are free from residues (Steffenak et al. 1991a). The purpose of the present study was to investigate the fate of residues of the quinolones oxolinic acid and flumequine in fish which are boiled or baked in the oven.

\section{Materials and methods \\ Salmon samples}

Salmon (Salmo salar) with residues of the quinolones oxolinic acid or flumequine were used in this investigation. The fish with oxo- linic acid residues were sampled more than six months after terminated treatment, while the fish with flumequine residues were sampled 70 days after withdrawel of the drug.

Dosage regimens were $25 \mathrm{mg} / \mathrm{kg}$ fish body weight for ten days, and $10 \mathrm{mg} / \mathrm{kg}$ for ten days for oxolinic acid and flumequine, respectively. The sea water temperature in the oxolinic acid experiment was $6-14^{\circ} \mathrm{C}$, and in the flumequine experiment approx. $14^{\circ} \mathrm{C}$.

Samples of muscle, skin, and bone from raw, boiled and baked fish were analysed, as was the water in which the fish were boiled and the juice exuding from the baked fish.

\section{Cooking procedures}

One sample for boiling and one sample for baking were taken from each fish. All analyses were repeated on three or four fish in each case. Boiling: Fish samples of 75 - $200 \mathrm{~g}$ were placed in $200-250 \mathrm{ml}$ of boiling water and left until just cooked (flesh just loosening from the bone). Baking: Fish samples of $75-275 \mathrm{~g}$ 
Table 1. Residues of oxolinic acid (OX) and flumequine (FQ) in fish muscle, skin and bone, before and after boiling and baking in the oven, and in the boiling water and in juice exuded from the baked fish. Results are given as the average for three to four fish.

\begin{tabular}{cccccc}
\hline & & \multicolumn{3}{c}{ Tissue content (ng/g) } & \multirow{2}{*}{$\begin{array}{c}\text { Total amount } \\
\text { in water or juice } \\
\text { (ng) }\end{array}$} \\
\cline { 3 - 5 } Drug & $\begin{array}{c}\text { Treatment } \\
\text { of fish }\end{array}$ & Muscle & Skin & Bone & \\
\hline OX & Raw & 0 & 35 & 164 & 625 \\
& Boiled & 6 & 12 & 46 & 23 \\
& Baked & 7 & 17 & 57 & \\
FQ & Raw & 0 & 36 & 465 & 600 \\
& Boiled & 0 & 58 & 493 & 104 \\
\hline
\end{tabular}

were packed in aluminium foil and put into a preheated oven $\left(200^{\circ} \mathrm{C}\right)$ and again left until just cooked.

\section{Methods}

Muscle, skin, and bone samples from raw and cooked fish containing oxolinic acid and flumequine were analysed by the method of Steffenak et al. (1991b). The sensitivity of the method for the determination of oxolinic acid was $5 \mathrm{ng} / \mathrm{g}$, and for the determination of flumequine $10 \mathrm{ng} / \mathrm{g}$. All samples of skin and bone were finely divided with a pair of scissors and left in the extraction fluid over night to extract the drug.

Water samples, boiling water and juice from baked fish, were analysed by a modified version of the method of Rogstad et al. (1989).

\section{Results and discussion}

The results are presented in Table 1 . No residues of oxolinic acid were found in raw fish muscle. After cooking, however, residues were detected in both boiled and baked muscle. The oxolinic acid content in both skin and bone was lower after boiling and baking in the oven than in the raw fish. Analysis of the boiling water and of the juice excuding from the baked fish, showed that oxolinic acid leaked out during preparation. The oxolinic acid content in boiled fish seemed to be slightly lower than in baked fish.

The muscle samples from fish treated with flumequine were negative both before and after cooking. The levels of flumequine in the skin were slightly higher after boiling and baking than in the raw state. Bone samples also showed higher values after cooking. Flumequine was also found to have leaked out into the boiling water, and into the juice from the baked fish.

The higher levels of flumequine found in tissues after preparation of the fish were probably due to the heat treatment making flumequine more available for extraction. We did not detect residues of flumequine in the muscle after cooking, as we did for oxolinic acid. For both the quinolones investigated, some of the "reservoir « residues (Steffenak et al. 1991a) leaked out into the boiling water or the juice exuded from the baked fish. Although there may be no residues left in the raw fish muscle before preparation, the muscle may become contaminated with small amounts of the drug on cooking, due to leakage from the reservoirs. We detected residues of oxolinic 
acid in muscle tissue after boiling and baking even though no residues were detected before cooking. The reason why no flumequine residues were detected in the fish muscle after cooking might be that the detection limit of the method is higher for flumequine than for oxolinic acid, i.e. $10 \mathrm{ng} / \mathrm{g}$ and $5 \mathrm{ng} / \mathrm{g}$, respectively (Steffenak et al. 1991b).

Levels of oxolinic acid and flumequine in boiled fish seemed to be slightly lower than in baked fish. This is probably due to more of the residues leaking out into the boiling water than into the juice exuded from baked fish. Neither of the quinolones included in this study seemed to degrade at the temperatures reached in the fish on cooking.

Residues of a drug may persist in reservoirs in fish for prolonged periods after end of treatment (Steffenak et al. 1991a). The residue levels in fish found in this study thus indicate the magnitude of those which may be found in fish as consumed.

\section{Acknowledgements}

The study was supported by the Agricultural Research Council of Norway.

\section{References}

Nafstad I: Salg av legemidler i norsk fiskeoppdrett 1991. (Sale of drugs related to fish farming in Norway 1991). Norsk Vet.-T. 1992, 104, 215.

Rogstad A, Hormazabal V, Yndestad M: Simultaneous extraction and determination of oxolinic acid and flumequine in fish tissues by high performance liquid chromatography. J. liq. Chromatogr. 1989, 12, 3073-3086.

Steffenak I, Hormazabal V, Yndestad M: Reservoir of quinolone residues in fish. Food Addit. Contam. 1991a, 8, 777-780.

Steffenak I, Hormazabal V, Yndestad M: Rapid assay for the simultaneous determination of residues of oxolinic acid and flumequine in fish tissues by high-performance liquid chromatography. J. liq. Chromatogr. 1991b, 14, 61-70.

\begin{abstract}
Sammendrag
Effekten av varmebehandling, koking og baking, på rester av quinolonene oksolinsyre og flumequin i fisk. Effekten av varmebehandling på rester av quinolonene oksolinsyre og flumequin i fisk ble unders $ø$ kt. Laks med rester av oksolinsyre og flumequin ble kokt eller bakt i stekeovn. Prøver av rå og kokt muskel, skinn og ben ble unders $ø \mathrm{kt}$, i tillegg til vannet fisken ble kokt i og kraft fra bakingen av fisken. Oksolinsyre og flumequin ble ikke brutt ned ved de temperaturene som ble oppnådd ved koking og baking. Muskel som ikke inneholder rester kan bli kontaminert ved koking og baking av fisk på grunn av lekasje av rester fra reservoar i fisken.
\end{abstract}

(Received March 30, 1993; accepted June 16, 1994).

Reprints may be requested from: V. Hormazabal, Department of Food Hygiene, Norwegian College of Veterinary Medicine, P.O. Box 8146 - Dep., N-0033 Oslo 1, Norway. 
